\title{
Enhancement in Bell Pepper (Capsicum annuum L.) Plants with Application of Roholtiella sp. (Nostocales) under Soilless Cultivation
}

\author{
Adewale Suraj Bello ${ }^{1}{ }^{(D}$, Imen Saadaoui ${ }^{2}{ }^{(D)}$, Talaat Ahmed ${ }^{3}$, Helmi Hamdi ${ }^{2} \mathbb{D}$, Maroua Cherif ${ }^{2}$, \\ Tasneem Dalgamouni ${ }^{2}$, Ghamza Al Ghazal ${ }^{2}$ and Radhouane Ben-Hamadou ${ }^{1, *(D)}$
}

1 Department of Biological and Environmental Sciences, College of Arts and Sciences, Qatar University, Doha P.O. Box 2713, Qatar; a.suraj@qu.edu.qa

2 Center for Sustainable Development, Algal Technologies Program, Qatar University, Doha P.O. Box 2713, Qatar; imen.saadaoui@qu.edu.qa (I.S.); hhamdi@qu.edu.qa (H.H.); cherif.maroua@qu.edu.qa (M.C.); t.dalgamouni@qu.edu.qa (T.D.); ali88@qu.edu.qa (G.A.G.)

3 Environmental Science Centre, Qatar University, Doha P.O. Box 2713, Qatar; t.alfattah@qu.edu.qa

* Correspondence: benhamadou@qu.edu.qa; Tel.: +974-44036454; Fax: +974-44034531

Citation: Bello, A.S.; Saadaoui, I.; Ahmed, T.; Hamdi, H.; Cherif, M.; Dalgamouni, T.; Al Ghazal, G.; Ben-Hamadou, R. Enhancement in Bell Pepper (Capsicum annuum L.) Plants with Application of Roholtiella sp. (Nostocales) under Soilless Cultivation. Agronomy 2021, 11, 1624. https://doi.org/10.3390/ agronomy11081624

Academic Editors: Roberto D'Amato and Juan Jose Rios

Received: 15 July 2021

Accepted: 6 August 2021

Published: 16 August 2021

Publisher's Note: MDPI stays neutral with regard to jurisdictional claims in published maps and institutional affiliations.

Copyright: (c) 2021 by the authors Licensee MDPI, Basel, Switzerland. This article is an open access article distributed under the terms and conditions of the Creative Commons Attribution (CC BY) license (https:// creativecommons.org/licenses/by/ $4.0 /)$.

\begin{abstract}
Cyanobacteria are found to be renewable and sustainable additives for growth improvement in crops. Extracts and biomass of three nitrogen-fixing cyanobacteria namely, Roholtiella sp. (QUCCCM97), Nostoc ellipsosporum (QUCCCM99), and Desmonostoc danxiaense (QUCCCM112) isolated from Qatar desert environment were tested for their ability to enhance the growth of bell pepper (Capsicum annuum L.) seedlings. Soilless cultivation experiments were carried out by applying the biomass and the aqueous extract of the three cyanobacteria separately. Seedlings were transplanted to Hoagland's solution under regulated conditions. In total, 2, 4, and $6 \mathrm{~mL} \mathrm{~L}^{-1}$ of the three microalgae extract as well as 1 and $2 \mathrm{mg} \mathrm{L}^{-1}$ of the three microalgae biomasses (as biofertilizer) were added to the Hoagland solution. An assessment of seedling growth parameters such as shoot length, root length, fresh weight, dry weight, spad index, number of leaves per plant, and growth rate was performed. However, among the different doses and concentrations of investigated QUCCCM97, 99, and 112 , our findings revealed that shoot length $(\mathrm{cm})$, root length $(\mathrm{cm})$, fresh weight $(\mathrm{g})$, the number of leaves per plant, and growth rate were positively affected and significantly increased at maximum dose/concentration compared to control plants. With QUCCCM97, shoot length, root length, fresh weight, the number of leaves, and the growth rate increased by $17.5 \%, 40.3 \%, 26.0 \%, 21.6 \%$, and $22.8 \%$, respectively, compared to the control. Additionally, with QUCCCM99, the same parameters increased by $12.3 \%, 25.3 \%, 15.1 \%, 9.3 \%, 51.8 \%$, respectively. While in presence of QUCCCM112, they increased by $8.7 \%, 30.1 \%, 15.6 \%, 5.4 \%, 48.6 \%$, respectively. Our results demonstrated that extracts and biomass of cyanobacteria strains investigated here, and particularly Roholtiella sp. (Nostocales), have an enhancement potential of the seedling growth and could be used in modern agriculture to enhance productivity under the soilless system and ensure sustainability.
\end{abstract}

Keywords: aqueous extract; Capsicum annuum; cyanobacteria biomass; growth enhancer; soilless cultivation system

\section{Introduction}

The persistent excessive use of chemical fertilizers leads to an increase in crop output but not without adverse/detrimental effects on the environment such as a rapid decrease in soil quality and fertility [1,2]. Additionally, it can cause biodiversity decline, eutrophication, and global ecological degradation [3-7]. In this regard, several fertilizing alternatives have been proposed to reduce the cost and environmental impacts of chemical fertilizers. Algae are preferred substitutes for chemical fertilizers and can be used as biofertilizers due to their potential of enhancing the general health conditions of plants with the ability to 
enhance soil fertility and productivity [8-10]. Aside from being eco-friendly, biofertilizers have other beneficial characteristics such as their sustainability in cultivated soils. Besides, the application of biofertilizers mitigates the possible accumulation of different levels of chemical contaminants within the soil [11].

Cyanobacteria or blue-green algae (BGA) constitute the largest group of photosynthetic prokaryotes with a wider spread and huge diversity globally, mostly in the terrestrial and aquatic ecosystems [12-15]. Their presence in different ecosystems, particularly terrestrial, makes them an essential part of the soil microflora with the potential of increasing the productivity of soil either directly or indirectly [16-18]. The increasing BGA applications in the various sectors such as a source of food, animal feed, biofuel, biofertilizers, biostimulants, colorants, etc., is a result of their ability to synthesize high value-added products such as vitamins, pharmaceuticals, enzymes, and pharmacological probes in addition to proteins, lipids, and carbohydrates $[9,19,20]$.

Species of terrestrial cyanobacteria are predominantly found in the soil, living symbiotically by enhancing the soil productivity through atmospheric nitrogen fixation, decomposition of organic by-products and residues, heavy metal detoxification, pathogenic microorganism suppression, and moisture content maintenance, and to certain extent soil erosion prevention [21]. Additionally, terrestrial cyanobacteria facilitate the increment of trace elements in soil, which are vital for plant development and ion uptake, improve nitrogen content, significantly in arid soils [21]. They equally enhance the production of plant growth-promoting compounds/substances (e.g., phytohormones) [8,22-26]. The aqueous extracts were considered as we targeted to establish that phycobiliproteins are plant growth enhancers. However, our goal is to utilize cyanobacteria biomass as growth promoters because they are relatively cheap to produce, sustainable, and cost-effective for crop production when compared with the costly phycobiliprotein (i.e., it costs more than the bell pepper when used as an input).

Soilless methods for growing seedlings, as a sustainable option to mitigate the problem of water shortages, improve water use efficiency (WUE) thereby minimizing the quantity of water loss either through evaporation or drainage, and improve food production in arid regions (AR). Soilless growing of fruits, vegetables, and other crops in arid regions is a fast-developing agricultural practice, which has been enhancing food productivity and water use efficiency, in regions with limited extension of arable lands. A study conducted by [27] indicated that farming under the soilless system is likely to be the most sustainable alternative that will provide different types of crops with the utilization of less water, fewer fertilizers as well as little space, which will result in yield increase per unit area. The authors of [28] reported that green forage has the potential to be successfully produced within 8 days from sowing to harvesting using the soilless method. The highest values for fresh green yields are recorded coupled with adequate water utilization efficiency under the hydroponic system. This technique has been used successfully in the arid region.

Several studies have revealed the beneficial impacts of cyanobacteria as a source of biofertilizers to different crops such as cereals, e.g., rice (Oryza sativa L.), wheat (Triticum aestivum L.) [24], maize (Zea mays L.) [29], and radish (Raphanus sativus L.) [30]. However, much is yet to be investigated on the effect of cyanobacteria on other important crops such as medicinal plants, legumes, and vegetables. Accordingly, little has been done on investigating the effect of cyanobacteria as a growth promoter on most Capsicum species. Capsicum annuum L. has been widely cultivated because of its well-recognized health benefits to humans. Such benefits are but not limited to carotenoids, flavonoids, ascorbic acid, phenolic compounds as well as the pungent capsaicinoids [31]. Capsicum annuum L. in this study was a model, a methodology to testing plant growth promotion, but not the main goal of the study.

The aim of this study was therefore to investigate the effect of extracts and biomasses of three cyanobacteria species isolated from Qatari soils, namely Roholtiella sp. (QUCCCM97), Nostoc ellipsosporum (QUCCCM99), and Desmonostoc danxiaense (QUCCCM112) as potential 
growth promoters on the growth parameters and spad index of C. annuum seedlings in Hoagland solution.

\section{Materials and Methods}

\subsection{Plant Material and Culture Condition}

The vegetable crop species selected for the current research study was bell pepper (Capsicum annuum L.) belonging to the family, Solanaceae as a model for the study. The seedlings produced from certified bell pepper (BP) hybrid seeds "Lorca" were obtained from a commercial nursery in Qatar (Al Sulaiteen Agricultural and Industrial Complex; SAIC). Vigorous seedlings with relative uniformity in weight and morphological appearances were selected as the propagating materials to kick-start the experiment. The seedlings of 20 days old were grown in a $4 \times 4 \times 13 \mathrm{~cm}$ flower vase in a hydroponic Hoagland solution [32]. Sixteen vases were arranged in a box of $17 \times 27 \times 10 \mathrm{~cm}$ to form a block, which constitutes nine replicates $(n=9)$ (Figure 1$)$. Transplanted seedlings displaying four true leaves were selected in the entire case to maintain homogeneity.

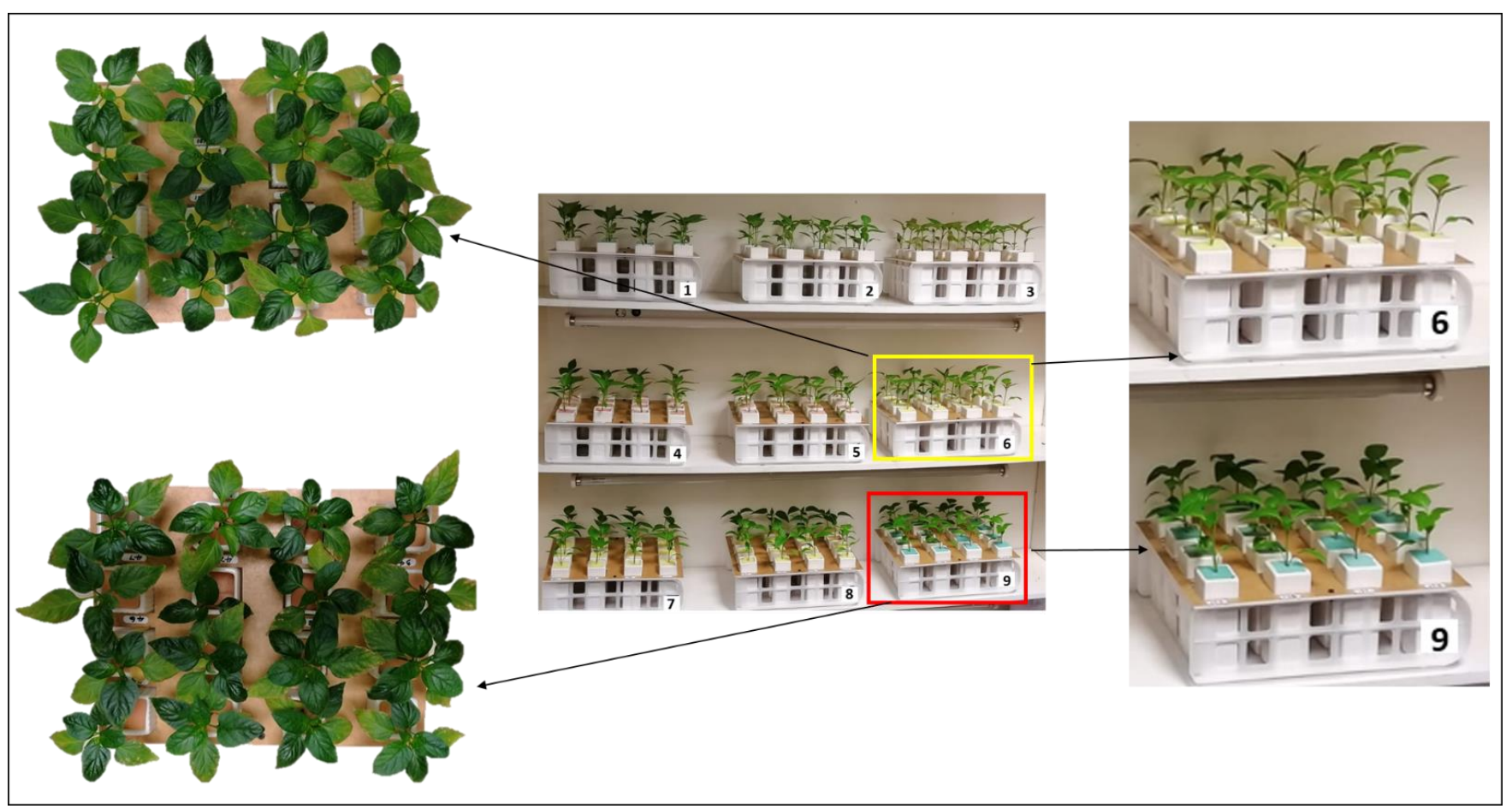

Figure 1. Treated and control seedlings in a block design $(n=9)$.

\subsection{Cyanobacteria Strains Cultivation and Growth Conditions}

Three freshwater filamentous and N-fixing cyanobacteria namely, Roholtiella sp. (QUCCCM97), Nostoc ellipsosporum (QUCCCM99), and Desmonostoc danxiaense (QUCCCM112) were selected for the current study based on their ability to produce different phycobiliproteins, i.e., phycoerythrin, phycocyanin, and phycobilin. These strains, isolated from the Qatar desert, belong to the Qatar University Culture Collection of Cyanobacteria and Microalgae (QUCCCM) [33]. The selection of these three strains was based on their different pigments content. One single colony of the cyanobacteria strain was used to inoculate a $5 \mathrm{~mL}$ volume of BG11 growth medium [34]. Subsequently incubated for 7 days at $30{ }^{\circ} \mathrm{C}$, a photon flux density of $100 \mu \mathrm{mol}$ photons $\mathrm{m}^{-2} \mathrm{~s}^{-1}$ and a 12:12 h dark:light cycle with $150 \mathrm{rpm}$ agitation using an illuminated shaker (Innova 44R, New Brunswick Scientific, Enfield, CT, USA). Then, the culture was gradually scaled up to $500 \mathrm{~mL}$ and incubated under the previously described conditions. Finally, an adequate volume was used to inoculate a DASGIP parallel 1L bioreactor system for phototrophic cultivation (\#76DG08PBBB, 
Eppendorf, Hauppauge, NY, USA). This culture was grown at $30^{\circ} \mathrm{C}, \mathrm{pH}$ 8, under $300 \mathrm{rpm}$ agitation to avoid settling of the cyanobacteria isolates, with $100 \mu \mathrm{mol}$ photons $\mathrm{m}^{-2} \mathrm{~s}^{-1}$, a 12:12 h dark:light regime and $5 \% \mathrm{CO}_{2}$ during the light phase [35]. After 15 days of incubation, the biomass from each species was harvested by centrifugation then freeze dried. All cultures were performed in duplicate.

\subsection{Preparation of Cyanobacteria Extracts}

The freeze-dried biomass obtained after 15 days of cultivation as described previously was divided into two parts. The first one (biomass) was used directly as a biofertilizer denoted as Roholtiella sp. QUCCCM97 $7_{\mathrm{bio}}$, Nostoc ellipsosporum QUCCCM99 ${ }_{\mathrm{bio}}$, and Desmonostoc danxiaense QUCCCM112 ${ }_{\text {bio }}$ while the second fraction was subjected to aqueous extraction. To this end, $100 \mathrm{mg}$ of dry biomass of each cyanobacteria strain was first washed with sterile distilled water then dissolved into $12.5 \mathrm{~mL}$ phosphate buffer $(0.1 \mathrm{M} \mathrm{pH} 6.0)$ before sonication for $10 \mathrm{~min}$ ( $5 \mathrm{~s}$ pulses of $8 \mathrm{~W}$ over $30 \mathrm{~s}$, on ice, Sonics VCX 130 Ultrasonic processor). The phosphate buffer solution was used to maintain the $\mathrm{pH}$ of the system and was not considered to play any role in the growth of the seedlings. Subsequently, extraction tubes were incubated at $4{ }^{\circ} \mathrm{C}$ for $24 \mathrm{~h}$. After centrifugation at $13,000 \mathrm{rpm}$ for $10 \mathrm{~min}$, aqueous extracts were collected and stored again at $4{ }^{\circ} \mathrm{C}$ in the dark and the residual biomass was subjected to repeated cycles of extraction until obtaining colorless biomass. Ultimately, aqueous extracts collected from the different cycles of extraction were mixed and stored in the dark at $4{ }^{\circ} \mathrm{C}$ until future use. In this case, the cyanobacteria extract stock solutions were denoted as Roholtiella sp. QUCCCM97 ${ }_{\text {extr }}$, Nostoc ellipsosporum QUCCCM99 $9_{\text {extr, }}$ and Desmonostoc danxiaense QUCCCM112 2 extr, respectively. The total time of the extraction

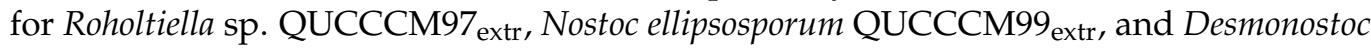
danxiaense QUCCCM112 extr (from cell break up to the analysis of pigments) did not exceed $30 \mathrm{~h}$.

\subsection{Cyanobacteria and Its Characterization}

\subsubsection{Morphological Characterization}

The cyanobacterial strains Roholtiella sp. (QUCCCM97), Nostoc ellipsosporum (QUCCCM99), and Desmonostoc danxiaense (QUCCCM112) were used in the present study. The three strains QUCCCM97, 99, and 112 underwent morphological observations and the morphology analysis of each of the three strains was examined by light microscopy under the magnification of $100 \times$ Figure 2. Additionally, the characterization of the aqueous extracts was conducted by spectrophotometric analysis. Analyses were executed using a fluorescence spectrophotometer (Synergy H4 Hybrid multi-mode microplate Reader. Bio Tek Instruments, Inc., Winooski, VT, USA). Steady and unbroken spectra of absorbance denoted as $\lambda$ (300 to $800 \mathrm{~nm}$ ) were amassed (Figure 3).
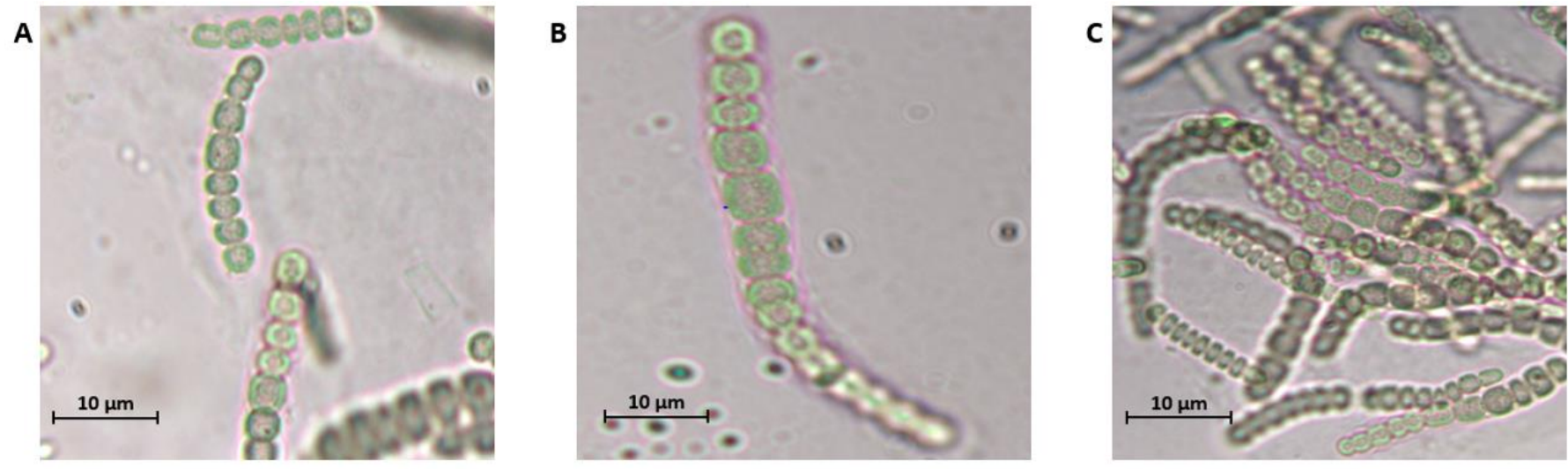

Figure 2. Microscopic observation of the three filamentous cyanobacteria species used in this study: (A) Roholtiella sp. (QUCCCM97), (B) Nostoc ellipsosporum (QUCCCM99), (C) Desmonostoc danxiaense (QUCCCM112). 


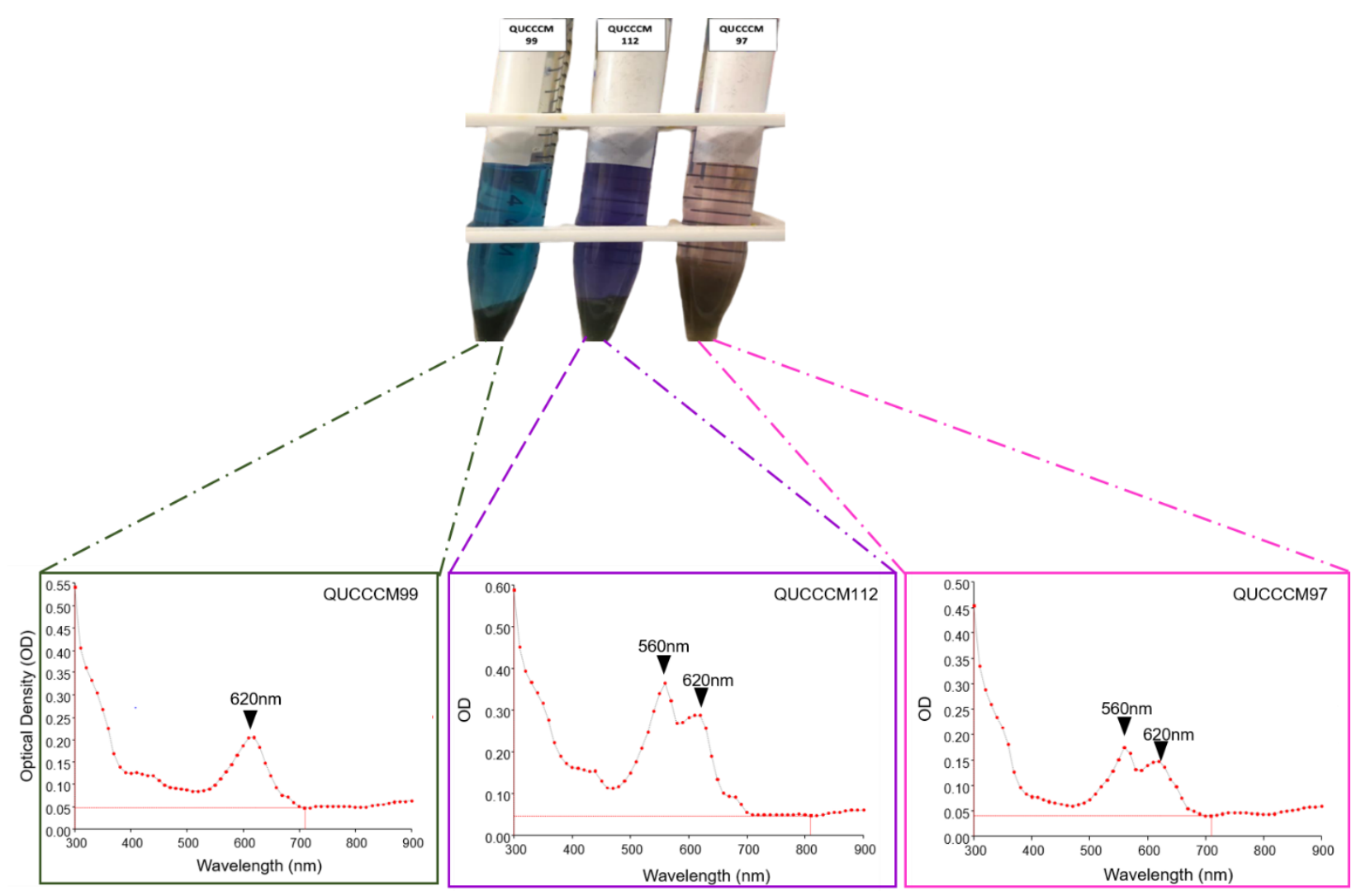

Figure 3. Aqueous extracts and the correspondent spectral scan of the strains Nostoc ellipsosporum (QUCCCM99), Desmonostoc danxiaense (QUCCCM112), and Roholtiella sp. (QUCCCM97). QUCCCM99 presented a high absorbance at $620 \mathrm{~nm}$ corresponding to maximum absorbance of the Phycocyanin while QUCCCM97 and QUCCCM112 presented two peaks of absorbance at 560 and $620 \mathrm{~nm}$. These peaks correspond to the $\lambda_{\max }$ of phycoerythrin and phycocyanin, respectively.

\subsubsection{DNA Extraction and Gene Sequencing}

For further identification, the molecular analysis of each cyanobacteria strain was examined through the sequencing of the 16S rDNA of the three strains, isolated from the Qatar desert environment, namely QUCCCM97, 99, and 112, respectively. The cultured DNA was harvested for analysis during the rapid growth stage and subsequently concentrated via centrifugation. Total genomic DNA was isolated by applying a method previously used by [36] with slight modifications [37]. The amplification of 16S rDNA genes was conducted by utilizing both primers BS1F (5' GATCCTKGCTCAGGATKAACGCTGGC $3^{\prime}$ ) and 920R ( $5^{\prime}$ TTTGCGGCCGCTCTGTGTGCC $\left.3^{\prime}\right)$. The PCR amplification was performed using the SuperFiTM PCR Master Mix (Thermo Fisher Scientific, Waltham, MA, USA). The purification of the PCR products was performed using ExoSAP-IT PCR Product Cleanup Reagent (Affymetrix, Santa Clara, CA, USA). The DNA concentration was determined by NanoDrop 2000c/2000 UV-Vis Spectrophotometer (Thermo Scientific, Wilmington, NC, USA). The sequencing of the purified DNA fragment was carried out by Genetic Analyzer 3500 (Applied Biosystems, CA, USA), using the same primers used for the PCR amplification in addition to two other internal primers, i.e., BSL4F (5'GYAACGAGCGCAACCC $3^{\prime}$ ) and BSL8R ( $5^{\prime}$ AAGGAGGTGATCCAGCCGCA $3^{\prime}$ ). Assembled sequences were submitted to GenBank and the accession numbers are provided in Table 1. 
Table 1. GenBank accession numbers and molecular classification of the strains.

\begin{tabular}{ccc}
\hline Strain/Isolate & GenBank Accession Number & Molecular Classification \\
\hline QUCCCM97 & MW791421 & Roholtiella sp. \\
QUCCCM99 & MW791422 & Nostoc ellipsosporum \\
QUCCCM112 & MW791423 & Desmonostoc danxiaense \\
\hline
\end{tabular}

\subsubsection{Phylogenetic Analysis}

The $16 \mathrm{~S}$ rDNA sequences of the three cyanobacteria strains were locally aligned using the Basic Local Alignment Search Tool (BlastN). Type strains and strains with sequenced genomes were downloaded for analyses. Alignment was performed by MUSCLE [38] as implemented in MEGA X software. Phylogenetic and molecular evolutionary analyses were conducted using MEGA X $[39,40]$.

\subsection{Experimental Design}

The bell pepper growth experiment was conducted at Qatar University, Department of Biological and Environmental Sciences, in January-February 2020. The study utilized the revamped deep-water culture (DWC) hydroponic system. This method was preferred because it allows continuous access to nutrients to enhance the faster growth of the plants. However, a modification of the construction of the system was essential to minimize the utilization of the nutrient solution. The nutrient solution replenishment was conducted every 7 days of the total 21-day experiment. The shoot length of the plant was measured at $T_{i}$ (initial) and $T_{f}$ (final), and other measured parameters include shoot length, root length, spad index, biomass (fresh and dry weight), growth rate, and the number of leaves. Cyanobacteria biomass, its aqueous extract, and Hoagland solution were used as growth media. The modified Hoagland prescription was as follows: $\mathrm{Ca}\left(\mathrm{NO}_{3}\right)_{2} \cdot 4 \mathrm{H}_{2} \mathrm{O}$, $1.250 \mathrm{~g} \mathrm{~L}^{-1} ; \mathrm{KNO}_{3}, 0.410 \mathrm{~g} \mathrm{~L}^{-1} ; \mathrm{NH}_{4} \mathrm{H}_{2} \mathrm{PO}_{4}, 0.280 \mathrm{~g} \mathrm{~L}^{-1} ; \mathrm{MgCl}_{2} \cdot 6 \mathrm{H}_{2} \mathrm{O}, 0.624 \mathrm{~g} \mathrm{~L}^{-1}$; $\mathrm{FeSO}_{4} \cdot 7 \mathrm{H}_{2} \mathrm{O}, 0.060 \mathrm{~g} \mathrm{~L}^{-1}$; EDTA-Na $\mathrm{E}_{2}, 0.080 \mathrm{~g} \mathrm{~L}^{-1} ; \mathrm{H}_{3} \mathrm{BO}_{3}, 0.006 \mathrm{~g} \mathrm{~L}^{-1} ; \mathrm{MnCl}_{2} \cdot 4 \mathrm{H}_{2} \mathrm{O}$, $0.04 \mathrm{~g} \mathrm{~L}^{-1} ; \mathrm{ZnSO}_{4} \cdot 7 \mathrm{H}_{2} \mathrm{O}, 4 \times 10^{-5} \mathrm{~g} \mathrm{~L}^{-1}$, and $\mathrm{CuSO}_{4} \cdot 5 \mathrm{H}_{2} \mathrm{O}, 4 \times 10^{-5} \mathrm{~g} \mathrm{~L}^{-1}$ [32]. The acidity of the solution was adjusted to a $\mathrm{pH}$ of $6.0 \pm 0.5$ [41]. The control treatment, a modified Hoagland nutrient solution [32] was denoted as $\operatorname{Tr}_{0}$. While the other treatments using cyanobacteria extracts and biomass were named $\operatorname{Tr}_{1}, \operatorname{Tr}_{2}, \operatorname{Tr}_{3}, \operatorname{Tr}_{4}$, and $\operatorname{Tr}_{5}$, respectively. Each treatment was replicated nine times, under nine replicate blocks among the arranged containers/reservoirs.

The summary of the treatments is as follows:

$\operatorname{Tr}_{0}$-Control- $\%$ extract and biomass (1 L Hoagland solution)

Extracts from QUCCCM X

$\operatorname{Tr}_{1}-\left(2 \mathrm{~mL} \mathrm{~L}^{-1}\right)-0.2 \%$ concentration $(2 \mathrm{~mL}$ extract of $X$ in $1 \mathrm{~L}$ Hoagland solution)

$\operatorname{Tr}_{2}-\left(4 \mathrm{~mL} \mathrm{~L}^{-1}\right)-0.4 \%$ concentration $(4 \mathrm{~mL}$ extract of $\mathrm{X}$ in 1 L Hoagland solution)

$\operatorname{Tr}_{3}-\left(6 \mathrm{~mL} \mathrm{~L}^{-1}\right)-0.6 \%$ concentration $(6 \mathrm{~mL}$ extract of $\mathrm{X}$ in $1 \mathrm{~L}$ Hoagland solution)

Biomass from QUCCCM X

$\operatorname{Tr}_{4}-\left(1 \mathrm{mg} \mathrm{L}^{-1}\right)-0.1 \%$ concentration (1 mg biomass of $\mathrm{X}$ in 1 L Hoagland solution)

$\mathrm{Tr}_{5}-\left(2 \mathrm{mg} \mathrm{L}^{-1}\right)-0.2 \%$ concentration ( $2 \mathrm{mg}$ biomass of $\mathrm{X}$ in $1 \mathrm{~L}$ Hoagland solution)

Where X refers to 97, 99, or 112 for the strains Roholtiella sp. (QUCCCM97), Nostoc ellipsosporum (QUCCCM99), and Desmonostoc danxiaense (QUCCCM112), respectively; $\operatorname{Tr}_{1}-$ $\mathrm{Tr}_{5}$ are different treatments with different concentrations. $\operatorname{Tr}_{1}-\mathrm{Tr}_{3}$-for extract, while $\mathrm{Tr}_{4}-\mathrm{Tr}_{5}$-for biomass.

\subsection{Growth Parameter and Spad Index}

As previously mentioned, this study was conducted to investigate the effects of microalgae extracts and biomass as growth promoters on bell pepper seedlings by considering the following vegetative growth parameters: shoot length, root length, fresh weight, dry weight, spad index, number of leaves, and growth rate.

Shoot length $(\mathrm{cm})$-SL 
The shoot length of bell pepper was taken from the top of support assumed to be the base up to the topmost part where the leaves are fully opened by using a measuring scale, and then the average was recorded. The measurement was carried out at the commencement and completion of the experiment, respectively.

Root length (cm)-RL

The bell pepper root length was measured from the point/base beneath the soil down to the tip of the fully developed root (longest) with the use of a measuring scale and the average was recorded. The RL was measured at 19 days of the experiment.

Fresh weight $(\mathrm{g})$ - FW

The fresh weight of the whole plants was taken/recorded using an analytical scale for accuracy and the average was taken. The FW was measured on the expiration of the experiment on the 21st day.

Dry weight $(\mathrm{g})$-DW

The harvested plants were oven-dried at $60{ }^{\circ} \mathrm{C}$ (Genlab Drying Cabinet, Genlab Limited. Cheshire, UK) until the weight was found constant. Thereafter, an analytical balance was used to measure the weight for accuracy, and the average was calculated. The DW was taken days after 21 days of the experiment when the weight was found to be constant.

Spad index-SI

The spad index of bell pepper leaf was ascertained employing SPAD—02, chlorophyll meter (Konica Minolta Optics, Osaka, Japan). The spad index measurement was carried before the harvest/termination of the experiment 19 days after the experiment.

Number of leaves per plant-NL

The number of leaves in every plant was counted manually before the end of the experiment, just 19 days after the experiment.

Growth rate-GR

This was obtained by measuring the height of the seedling at two different times, at the commencement and end of the experiment while the experimental duration lasted 21 days. The initial and final height stage is assumed to be $\mathrm{Hi}$ and $\mathrm{Hf}$.

$$
G R=\frac{H f-H i}{T f-T i}
$$

GR — growth rate $\left(\mathrm{cm}^{\text {day }}{ }^{-1}\right), \mathrm{Hf}$-final height, $\mathrm{Hi}$-initial height, $\mathrm{Tf}$ - $\mathrm{Ti}$ - duration of experimentation.

\subsection{Data Analysis}

Data were analyzed following the procedure of analysis of variance (ANOVA) based on randomized complete block design (RCBD) using Minitab ${ }^{\circledR}$ software. Mean differences were compared through Tukey's post hoc test and was used to analyze the level of significant differences between treatments at a 5\% significance level ( $p \leq 0.05)$.

\section{Results}

\subsection{Cyanobacteria Characterization, Pigment, and Molecular Identification}

The morphology of each strain was observed under a microscope revealing their filamentous trichomes features as shown in Figure 2. Furthermore, the aqueous extracts of the strains Roholtiella sp. (QUCCCM97), Nostoc ellipsosporum (QUCCCM99) and Desmonostoc danxiaense (QUCCCM112) were characterized by optical measurements of the spectral absorption within the range of 300-800 $\mathrm{nm}$. The absorbance band or spectra of the phycocyanin and phycoerythrin in the targeted compounds are shown in Figure 3. The obtained spectrophotometric bands or signatures of phycocyanin and phycoerythrin vary in the shape, value of $\lambda_{\max }$, and position. The spectra showed the variation in their corresponding bands is related to the absorbance level. This could be further supported by spectra bands exhibited by the same pigments as narrated in a relevant study [42]. The aqueous extracts of Nostoc ellipsosporum QUCCCM99 ${ }_{\text {extr, Desmonostoc danxiaense QUCCCM112 }}$ extr, 
and Roholtiella sp. QUCCCM97 extr revealed three different colors of blue-green, purple, and pink, respectively. The investigation of the nature of these pigments based on their $\lambda_{\max }$ of absorbance via spectral scan proved that Nostoc ellipsosporum (QUCCCM99) presented phycocyanin with $\lambda_{\max }=620 \mathrm{~nm}$. However, Desmonostoc danxiaense (QUCCCM112) and Roholtiella sp. (QUCCCM97) presented an additional peak at $\lambda_{\max }=560 \mathrm{~nm}$, corresponding to the phycoerythrin. Results proved that the absorbance at $620 \mathrm{~nm}$ of Desmonostoc danxiaense (QUCCCM112) is higher than the other strain. Hence, this explains the dark color of the aqueous extract.

However, considering the nature of phycoerythrin and phycocyanin in this study, phycoerythrin exhibited higher sensitivity with the absorbance technique compared to the phycocyanin in the various extracts analyzed in this study. Overall, the two strong signals exhibited by Roholtiella sp. QUCCCM97 extr $_{\text {and Desmonostoc danxiaense QUCCCM112 }}$ extr

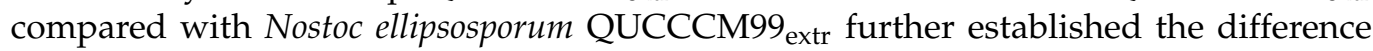
in the sensitivity of the strains investigated (Figure 3). Furthermore, the blast search results indicated that the sequence of the 16S rDNA gene in the three strains QUCCCM97 (GenBank accession number-MW791421), QUCCCM99 (accession number-MW791422), and QUCCCM112 (accession number-MW791423) is significantly alike the corresponding species of Roholtiella, Nostoc, and Desmonostoc, respectively, as illustrated in a tabular form below (Table 1). Phylogenetic analyses (Figure 4) drew on 16S rDNA sequences of 47 specimens of the selected major groups of genera employed as outgroups upon which our strains were placed for identification. Our strains were found to belong to the Roholtialla, Nostoc, and Desmonostoc generic clade, respectively (Figure 4).

\subsection{Growth Parameters of Seedlings and Spad Index at the End of the Experimental Period}

\subsubsection{Efficacy of Roholtiella sp. (QUCCCM97) Extracts and Biomass as a Growth Enhancer}

As illustrated in Figure 5, the efficacies/effectiveness of Roholtiella sp. (QUCCCM97) extract and biomass in enhancing the growth parameters and spad index of seedlings were very prominent at different concentrations. For seedlings treated with $0.2 \%$ or $2 \mathrm{~mL} \mathrm{~L}^{-1}$ $\left(\operatorname{Tr}_{1}\right), 0.4 \%$ or $4 \mathrm{~mL} \mathrm{~L}^{-1}\left(\operatorname{Tr}_{2}\right)$, and $0.6 \%$ or $6 \mathrm{~mL} \mathrm{~L}^{-1}\left(\operatorname{Tr}_{3}\right)$ extract concentrations showed increased shoot length by $2.4 \%, 8.0 \%$, and $17.5 \%$, respectively. In addition, biomass concentrations of $0.1 \%$ or $1 \mathrm{mg} \mathrm{L}^{-1}\left(\operatorname{Tr}_{4}\right)$ and $0.2 \%$ or $2 \mathrm{mg} \mathrm{L}^{-1}\left(\operatorname{Tr}_{5}\right)$ increased by $3.0 \%$ and $4.1 \%$, respectively, compared with the control group. Similarly, treatments $0.2 \%$ or $2 \mathrm{~mL} \mathrm{~L}^{-1}$ $\left(\operatorname{Tr}_{1}\right), 0.4 \%$ or $4 \mathrm{~mL} \mathrm{~L}^{-1}\left(\operatorname{Tr}_{2}\right), 0.6 \%$ or $6 \mathrm{~mL} \mathrm{~L}^{-1}\left(\operatorname{Tr}_{3}\right), 0.1 \%$ or $1 \mathrm{mg} \mathrm{L}^{-1}\left(\operatorname{Tr}_{4}\right)$, and $0.2 \%$ or $2 \mathrm{mg} \mathrm{L}^{-1}\left(\operatorname{Tr}_{5}\right)$ showed increased root length by $19.5 \%, 29.3 \%, 40.3 \%, 10.9 \%$, and $21.6 \%$ than the control group. The treatments trend showed higher fresh and dry weights by $19.3 \%, 8.9 \%, 26.0 \%, 5.2 \%, 10.4 \%, 16.7 \%, 11.1 \%, 33.3 \%$, and $5.6 \%$, respectively. Additionally, at the same concentrations, BP seedlings showed a higher spad index, number of leaves per plant, and growth rate by $10.1 \%, 6.7 \%, 3.7 \%, 9.9 \%$, and $2.2 \%$ for the spad index; $7.8 \%$. $10.8 \%, 21.6 \%, 6.2 \%$, and $7.8 \%$ for the number of leaves per plant; $27.3 \%, 10.5 \%, 22.8 \%$, $33.3 \%$, and $37.9 \%$ for the growth rate, respectively, than the control group. 


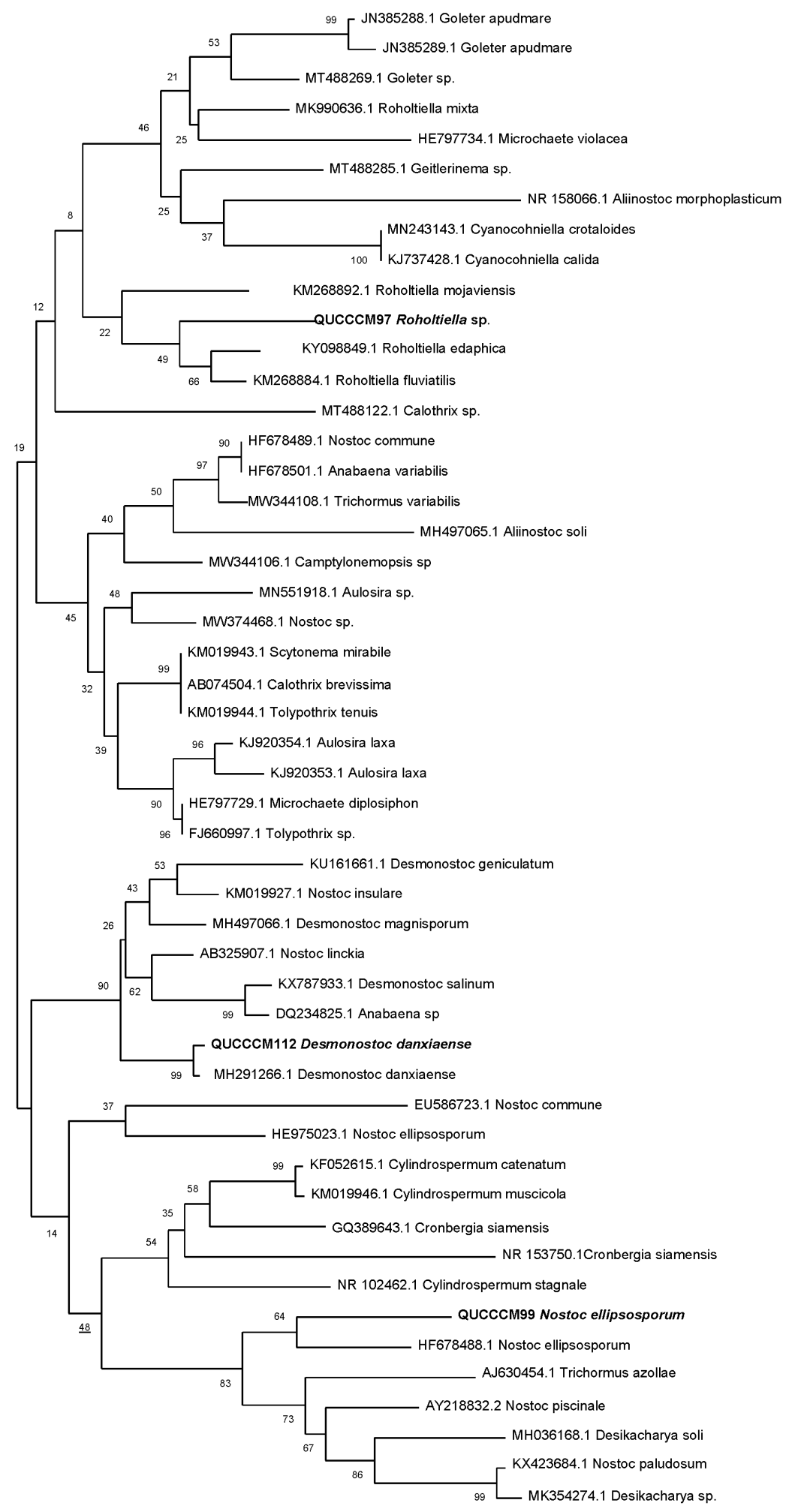

0.0050

Figure 4. Phylogenetic tree based on neighbor-joining method using MEGA $X$ software. The percentage of replicate trees in which the associated taxa clustered together in the bootstrap test (1000 replicates) are shown next to the branches. 


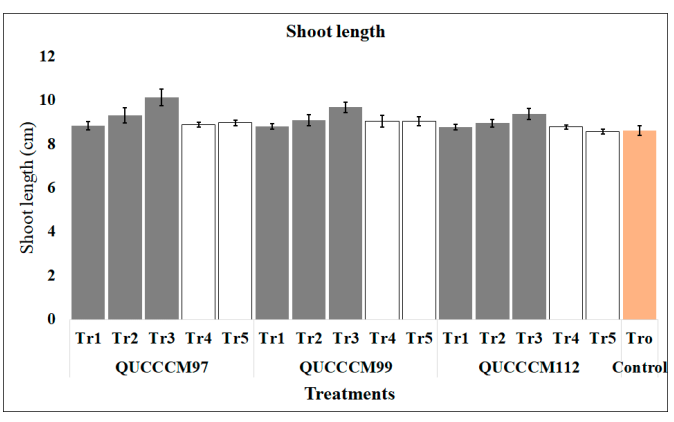

(a)

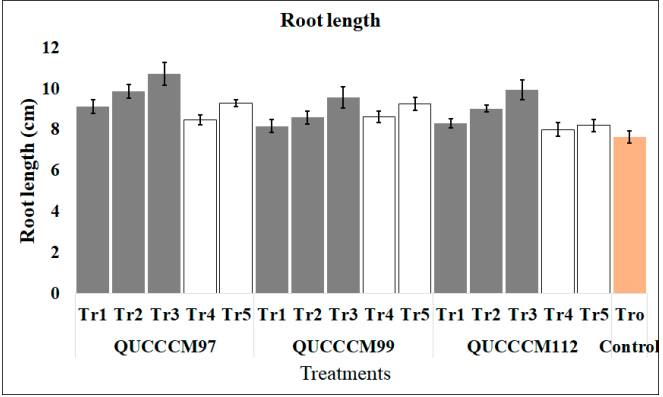

(b)

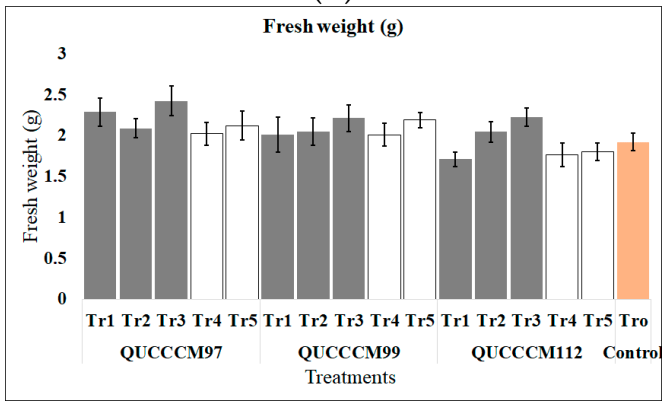

(c)

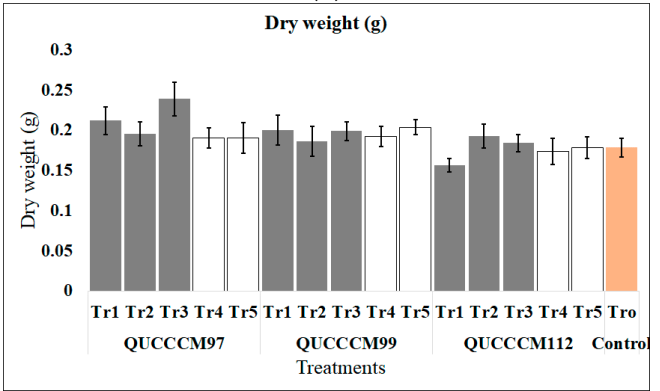

(d)

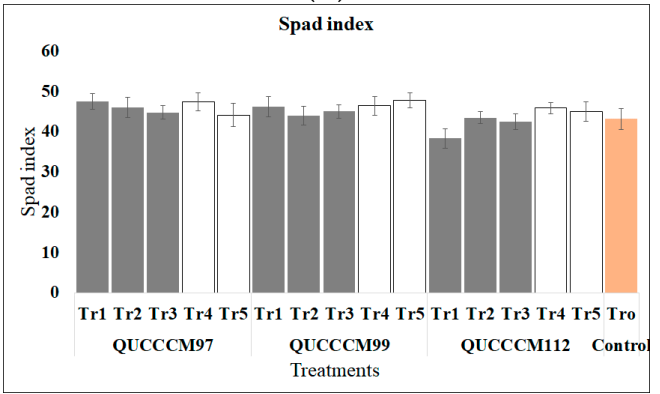

(e)

Figure 5. Cont. 


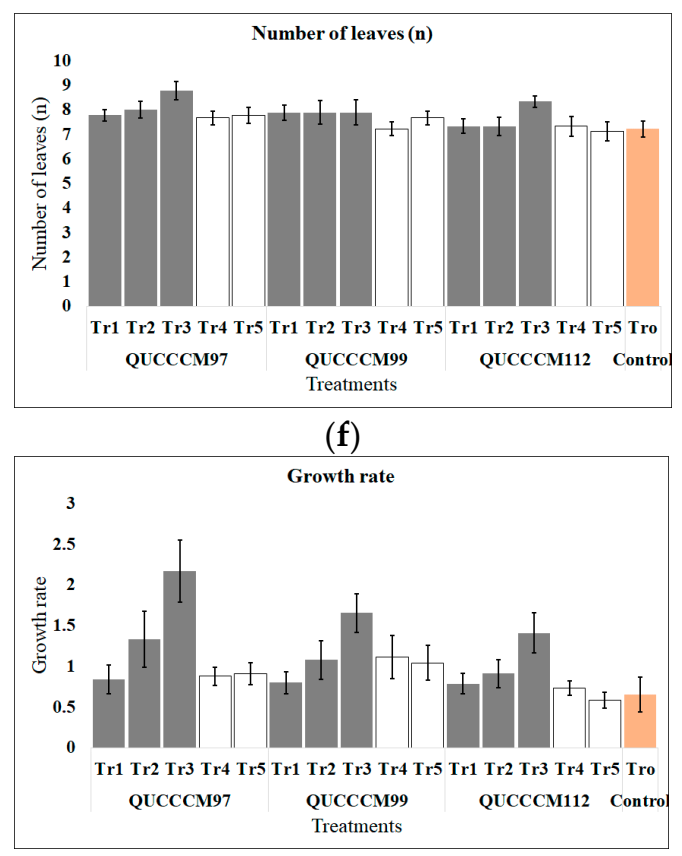

(g)

Figure 5. (a-g) Shoot length, root length, fresh weight, dry weight, spad index, number of leaves, and growth rate of bell pepper untreated seedlings $\left(\operatorname{Tr}_{0}\right)$, treated with $0.2 \%$ or $2 \mathrm{~mL} \mathrm{~L}^{-1}\left(\operatorname{Tr}_{1}\right), 0.4 \%$ or $4 \mathrm{~mL} \mathrm{~L}^{-1}\left(\operatorname{Tr}_{2}\right)$, and $0.6 \%$ or $6 \mathrm{~mL} \mathrm{~L}^{-1}\left(\operatorname{Tr}_{3}\right)$ of the three microalgae extracts. Additionally, with $0.1 \%$ or $1 \mathrm{mg} \mathrm{L}^{-1}\left(\operatorname{Tr}_{4}\right)$ and $0.2 \%$ or $2 \mathrm{mg} \mathrm{L}^{-1}\left(\operatorname{Tr}_{5}\right)$ of the three microalgae biomass.

\subsubsection{Efficacy of Nostoc ellipsosporum (QUCCCM99) Extracts and Biomass as a} Growth Enhancer

Similarly, when compared to the control group, Nostoc ellipsosporum (QUCCCM99) extracts and biomass exhibited increased growth parameters and spad index. Seedlings treated with $0.2 \%$ or $2 \mathrm{~mL} \mathrm{~L}^{-1}\left(\operatorname{Tr}_{1}\right), 0.4 \%$ or $4 \mathrm{~mL} \mathrm{~L}^{-1}\left(\operatorname{Tr}_{2}\right), 0.6 \%$ or $6 \mathrm{~mL} \mathrm{~L}^{-1}\left(\operatorname{Tr}_{3}\right)$ extract concentrations showed increased seedling shoot length (by 2.1\%, 5.5\%, and 12.3\%). With biomass concentration of $0.1 \%$ or $1 \mathrm{mg} \mathrm{L}^{-1}\left(\operatorname{Tr}_{4}\right)$ and $0.2 \%$ or $2 \mathrm{mg} \mathrm{L}^{-1}\left(\operatorname{Tr}_{5}\right)$ increased by $5.1 \%$ and $4.8 \%$, respectively. Equally, seedlings treatments $0.2 \%$ or $2 \mathrm{~mL} \mathrm{~L}^{-1}\left(\operatorname{Tr}_{1}\right), 0.4 \%$ or $4 \mathrm{~mL} \mathrm{~L}^{-1}\left(\operatorname{Tr}_{2}\right), 0.6 \%$ or $6 \mathrm{~mL} \mathrm{~L}^{-1}\left(\operatorname{Tr}_{3}\right), 0.1 \%$ or $1 \mathrm{mg} \mathrm{L}-1\left(\operatorname{Tr}_{4}\right)$, and $0.2 \%$ or $2 \mathrm{mg} \mathrm{L}^{-1}\left(\operatorname{Tr}_{5}\right)$ showed increased seedling root length by $7.1 \%, 12.4 \%, 25.3 \%, 12.8 \%$, and $21.2 \%$ than the control group. The treatments trend showed higher fresh and dry weights by $4.7 \%, 5.3 \%$, $15.1 \%, 4.7 \%, 14.1 \%$, and $11.1 \%, 5.6 \%, 33.3 \%, 11.1 \%$, and $11.1 \%$, respectively. Additionally, at the same concentrations, the seedlings showed a higher spad index, the number of leaves per plant, and growth rate by $7.1 \%, 2.0 \%, 4.4 \%, 7.6 \%$, and $10.8 \%$ for the spad index; $9.3 \%$. $9.3 \%, 9.3 \%, 6.2 \%$, and $0.0 \%$ for the number of leaves per plant; $21.2 \%, 63.64 \%, 51.8 \%, 68.2 \%$, and $57.6 \%$ for the growth rate, respectively, than the control group.

3.2.3. Efficacy of Desmonostoc danxiaense (QUCCCM112) Extracts and Biomass as a Growth Enhancer

Likewise, when compared to the control group, Desmonostoc danxiaense (QUCCCM112) extracts and biomass exhibited increased growth parameters and spad index. Seedlings treated with $0.2 \%$ or $2 \mathrm{~mL} \mathrm{~L}^{-1}\left(\operatorname{Tr}_{1}\right), 0.4 \%$ or $4 \mathrm{~mL} \mathrm{~L}-1\left(\operatorname{Tr}_{2}\right), 0.6 \%$ or $6 \mathrm{~mL} \mathrm{~L}^{-1}\left(\operatorname{Tr}_{3}\right)$ extract concentrations showed increased seedling shoot length (by $1.7 \%, 3.9 \%$, and $8.7 \%$, respectively). With biomass concentrations of $0.1 \%$ or $1 \mathrm{mg} \mathrm{L}^{-1}\left(\mathrm{Tr}_{4}\right)$ and $0.2 \%$ or $2 \mathrm{mg} \mathrm{L}^{-1}$ $\left(\operatorname{Tr}_{5}\right)$ is increased (by $1.9 \%$ and $-0.7 \%$ ), respectively. Equally, seedlings treatments $0.2 \%$ or $2 \mathrm{~mL} \mathrm{~L}^{-1}\left(\operatorname{Tr}_{1}\right), 0.4 \%$ or $4 \mathrm{~mL} \mathrm{~L}^{-1}\left(\operatorname{Tr}_{2}\right), 0.6 \%$ or $6 \mathrm{~mL} \mathrm{~L}^{-1}\left(\operatorname{Tr}_{3}\right), 0.1 \%$ or $1 \mathrm{mg} \mathrm{L}^{-1}\left(\operatorname{Tr}_{4}\right)$, and $0.2 \%$ or $2 \mathrm{mg} \mathrm{L}^{-1}\left(\mathrm{Tr}_{5}\right)$ showed increased seedling root length (by $8.8 \%, 18.2 \%, 30.1 \%$, $4.8 \%$, and $7.3 \%$ ) than the control group. The treatment trend showed higher fresh and dry weights at $\left(\mathrm{Tr}_{2}\right) 6.3 \%,\left(\mathrm{Tr}_{3}\right) 15.6 \%$, for the fresh weigh and $\left(\mathrm{Tr}_{2}\right) 5.6 \%$ for the dry weight 
than the control group, respectively. Likewise, at the same concentrations, the seedlings showed a higher spad index, the number of leaves per plant, and growth rate by $0.9 \%$ $\left(\operatorname{Tr}_{2}\right), 6.3 \%\left(\operatorname{Tr}_{4}\right)$, and $4.2 \%\left(\operatorname{Tr}_{5}\right)$ for the spad index. Similarly, $1.5 \%\left(\operatorname{Tr}_{1}\right), 1.5 \%\left(\operatorname{Tr}_{2}\right), 5.4 \%$ $\left(\operatorname{Tr}_{3}\right)$, and $1.5 \%\left(\operatorname{Tr}_{4}\right)$ for the number of leaves per plant; $20.0 \%\left(\operatorname{Tr}_{1}\right), 37.9 \%\left(\operatorname{Tr}_{2}\right), 48.6 \%$ $\left(\operatorname{Tr}_{3}\right)$, and $10.6 \%\left(\operatorname{Tr}_{4}\right)$ for the growth rate, respectively, than the control group. Interestingly, even with these positive impacts, the Desmonostoc danxiaense (QUCCCM112) extracts and biomass did not enhance growth parameters and spad index when compared with the control group at some concentrations. At $\operatorname{Tr}_{1}, \operatorname{Tr}_{4}$, and $\operatorname{Tr}_{5}$ for fresh weight; $\operatorname{Tr}_{1}$ and $\operatorname{Tr}_{4}$ for dry weight; $\operatorname{Tr}_{1}$ and $\mathrm{Tr}_{3}$ for the spad index; at $\mathrm{Tr}_{5}$ for both the number of leaves per plant and growth rate, respectively. All showed opposite/no effect when compared with control.

\subsubsection{Strain Nature, Pigment, Dose and Effect Comparison}

There is tremendous variation in the nature of the strains investigated that characterized the different spectra/bands and positions as displaced in Figure 3. However, in particular, Roholtiella sp. QUCCCM97extr had a significant impact on the shoot length, growth rate, root length, fresh weight, dry weight, spad index, and the number of leaves even at a minimal dose $\left(\operatorname{Tr}_{1}\right)$ Roholtiella sp. QUCCCM97extr because of the embedded phycoerythrin (Figure 5). Nevertheless, noticeable differences were obvious in these parameters studied at this maximum dose $\left(\mathrm{Tr}_{3}\right)$ with Nostoc ellipsosporum QUCCCM99extr and Desmonostoc danxiaense QUCCCM112extr which is an indication that Roholtiella sp. QUCCCM97extr has an impact that is more positive on the growth parameters investigated even at minimal dose, a significant difference in these parameters was achievable.

The statistical analysis revealed a clear indication of the significance of various treatments on the growth factors of bell pepper as shown in Table 2. Since $p$-value $=0.001$ shoot length (SL), 0.001 root length, 0.02 fresh weight, 0.007 number of leaves, 0.001 growth rate is less than 0.05 then we reject the null hypothesis and we conclude that there is a significant difference in these treatments at 0.05 significance level. However, in the case of dry weight, and spad index, there is no significant difference though the trend shows that quantitatively all treatments have a positive effect on growth parameters (Figure 5).

Table 2. Analysis of variance showing the statistical significance effect of various treatments on the growth parameters shoot length (SL), root length (RL), fresh weight (FW), dry weight (DW), spad index (CC), number of leaves (NL), and growth rate (GR) of seedlings. ${ }^{* *}$ Indicates highly significant differences at $0.05(5 \%)$ level, ns = not significant.

\begin{tabular}{ccccccccc}
\hline \multirow{2}{*}{ Source of Variation } & \multirow{2}{*}{ DF } & \multicolumn{7}{c}{ Mean Square (MS) } \\
\cline { 3 - 8 } & & SL & RL & FW & DW & CC & NL & GR \\
\hline Block & 8 & 0.979 & 3.8925 & 1.1712 & 0.0065 & 242.3572 & 5.7153 & 0.9544 \\
Treatment & 15 & $1.485^{* *}$ & $6.1416^{* *}$ & $0.3328^{* *}$ & $0.0029^{\text {ns }}$ & $50.0803^{\text {ns }}$ & $1.7884^{* *}$ & $1.5226^{* *}$ \\
Error & 120 & 0.386 & 0.8399 & 0.1245 & 0.00173 & 30.22 & 0.7801 & 0.3815 \\
Total & 143 & & & & & & \\
\hline
\end{tabular}

Furthermore, the comparative analysis revealed that there is a significant difference between a treated bell pepper and control for vegetative growth parameters viz. shoot length, root length, fresh weight, dry weight, spad index, number of leaves, and GL $(p<0.05)$ as shown in Table 3. Additionally, extracts and biomass from cyanobacteria strain Roholtiella sp. QUCCCM97, Nostoc ellipsosporum QUCCCM99, and Desmonostoc danxiaense QUCCCM112 tested on bell pepper growth parameters further showed a significant growth difference with the control seedlings as shown in Table 3. The effectiveness of various cyanobacteria extracts, and biomass treatments could also be compared as displayed in Tukey pairwise comparisons (Table 3). Means that do not share a letter affirmed to be significantly different while contrarily those that share a letter are not significantly different at $p<0.05$ in terms of their effect on the measured parameters. 


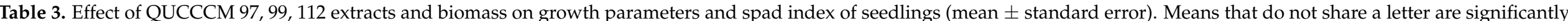

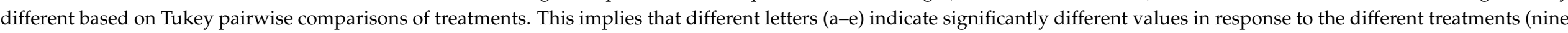
replicates per treatment).

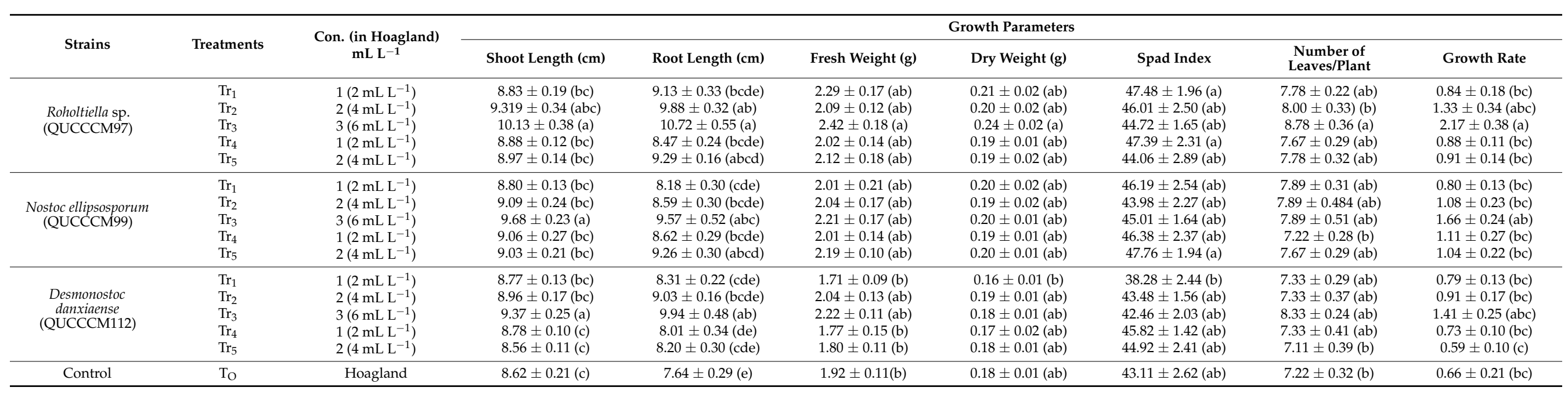


However, the biomass and extracts with the concentration of, respectively, $3 \mathrm{mg} \mathrm{L}^{-1} / 6 \mathrm{~mL}^{-1}$ gave the highest result while the application at lower concentrations of $1 \mathrm{mg} \mathrm{L}-1 / 2 \mathrm{~mL}^{-1}$ or $2 \mathrm{mg} \mathrm{L}^{-1} / 4 \mathrm{~mL}^{-1}$ yielded lesser growth when compared with the $6 \mathrm{~mL}^{-1}$ for biomass and $3 \mathrm{mg} \mathrm{L}^{-1}$ for extract concentrations.

\section{Discussion}

Several studies that address the application of algae as biostimulants and biofertilizers/enhancers have mostly focused on the application of BGA (cyanobacteria) on cereal crops, primarily rice $[43,44]$. Importantly, their potential to fix atmospheric nitrogen for plant use makes it essential in several agricultural cultivations [44-47]. Several microalgae extracts exhibited enhancing characteristics/properties on the development of crops as reported by previous studies [43]. Growth is stimulated because of biochemical/bioregulators such as auxin, gibberellins, and cytokines coupled with a reasonable amount of macro and micronutrients [48]. Reports on BGA as biostimulants on bell pepper are almost nonexistent, although bell pepper is rich in vitamins and antioxidants, particularly ascorbic acid and different carotenoids. Thus, they may have several therapeutic advantages, for example, improved eyesight and decreased potential risks associated with chronic ailments [49]. Several studies have shown that the presence of BGA in soil has the potential to positively influence plant growth. For instance, the authors of [50] showed positive impacts of cyanobacteria on vegetative and reproductive parameters of herbaceous plants. The results of our study indicated that the three cyanobacteria strains possessed the ability to significantly enhance several growth parameters when applied in different forms and doses to plants including shoot length, root length, fresh weight, dry weight, spad index, number of leaves, and growth rate parameters. This study showed that the usage of Roholtiella sp. QUCCCM97, Nostoc ellipsosporum QUCCCM99, and Desmonostoc danxiaense QUCCCM112 aqueous extracts and biomass enhanced the growth of seedlings as compared to control group.

Several studies have pointed out the positive impacts of cyanobacteria on plant development, nutrient consumption, and nitrogen fixation, leading to plant growth enhancement $[13,45,51,52]$. Our results are in line with these reports because the extracts and biomass of Roholtiella sp. QUCCC97, Nostoc ellipsosporum QUCCCM99, and Desmonostoc danxiaense QUCCCM112 were very rich in total nitrogen, and its bioavailable forms nitrate, ammonium, and nitrite. Consequently, treated seedlings had better and higher performance in the vegetative growth parameters. Additionally, other bioactive compounds aside from the nitrogenous level of cyanobacterial played vital roles in stimulating the growth of treated seedlings [53]. Furthermore, qualitatively and quantitatively, the phycocyanin and phycoerythrin are found in Roholtiella sp. QUCCCM97extr, Nostoc ellipsosporum QUCCCM99extr, and Desmonostoc danxiaense QUCCCM112extr of cultures were similar to study [54]. Phycocyanin was found in all extracts, appearing more in excess in Nostoc ellipsosporum QUCCCM99 than Desmonostoc danxiaense, and Roholtiella sp. of three species analyzed. The absorbance spectra of phycobiliproteins (phycoerythrin, phycocyanin) isolated from these strains of cyanobacteria (Roholtiella sp. QUCCCM97, Nostoc ellipsosporum QUCCCM99, and Desmonostoc danxiaense QUCCCM112) were remarkably similar and conform with the high peak wavelength absorbance maxima of phycobiliproteins investigated in similar studies and with slight variation in the range of $\lambda_{\max }$ (Figure 3). Several studies have equally shown that at the spectra peak of 620 and $565 \mathrm{~nm}$ of the highvalue phycobiliproteins (phycoerythrin, phycocyanin) could be found [42]. This further proved that our used strains contain these pigments as they were eventually responsible for the positive impacts on the investigated growth parameters.

Virtually all concentrations of Roholtiella sp. QUCCCM97, Nostoc ellipsosporum QUCCCM99, and Desmonostoc danxiaense QUCCCM112 extracts and biomass influenced statistically the shoot length and other growth factors. The obtained results corroborate the studies conducted previously [55,56]. Additionally, the study conducted by [57] showed that cyanobacteria aqueous extracts affect the growth parameters and performance of 
tomato plants. Accordingly, there was an increase in the length and diameter of the plant by $19 \%$ and $33 \%$, respectively, which is in line with current outcomes.

The application of the aqueous extracts of microalgae and biomass (Roholtiella sp. QUCCCM97, Nostoc ellipsosporum QUCCCM99, and Desmonostoc danxiaense QUCCCM112) enhanced plant growth and parameters compared to the controls in a positive manner. Interestingly, our results could be compared with those of [58] who observed greater growth and development in vegetative parameters (SL, RL, FW) as concentrations of Sargassum johnstonii extracts increase. In contrast, the authors of [59] observed greater plant growth factors with decreasing extract concentrations. Furthermore, our study revealed that all BGA strains Roholtiella sp. QUCCCM97, Nostoc ellipsosporum QUCCCM99, and Desmonostoc danxiaense QUCCCM112 positively enhanced the fresh mass of the seedling and this confirms data from earlier studies conducted on cyanobacteria [55,56,60,61]. For example, Spirulina plantensis can influence the fresh weight and fruit biomass of tomato plants by $48 \%$ and $43 \%$, respectively, when compared with untreated plants [57]. In another study, the effect of microalgae extracts was observed to be positive on the yield factors of winter wheat (variety Akteur). Applied doses with the highest extract concentrations of 1.5 and $1 \mathrm{~L} \mathrm{ha}^{-1}$ showed significant differences when compared with the control group [53]. In the study conducted by [60] on the potential of Arthrospira platensis (Spirulina platensis) as biostimulant, outcomes showed higher fresh weight in lettuce (L. sativa) due to the activity of cytokinin, which could be equally embedded in Roholtiella sp. QUCCCM97, Nostoc ellipsosporum QUCCCM99, and Desmonostoc danxiaense QUCCCM112.

However, the beneficial impacts of heterocystous cyanobacteria were previously assessed on the growth of pumpkin (Cucubita pepo L.) and cucumber (Cucumis sativus L.) seedlings from the application of Westiellopsis prolifica extracts $[13,62]$. The observed significant increase in the growth and development of both crops is in line with our results on bell pepper seedlings. A study conducted on the beneficial effects of cyanobacteria extracts on potato (Solanum tuberosum L.) established that the increase in the crop yields should not be seen only as of the nitrogen-fixing potential of cyanobacteria. It could also be a result of the endogenous growth-regulating substances synthesized by these cyanobacteria [13,63]. This assumption was duly supported because some non-nitrogen fixing cyanobacterial species e.g., Oscillatoria spp. and Phnomedium spp. improved the growth of different plants such as rice [64,65]. In addition, this is connected with the synthesis of growth-promoting compounds and essential vitamins such as folic acid, vit. B12, nicotinic acid as well as pantothenic acid, which are likely other reasons for the substantial growth, development, and yield of the treated plants [66].

\section{Conclusions}

In the current study, we closely examined the effect of extracts and biomass of three cyanobacteria strains namely, Roholtiella sp. QUCCCM97, Nostoc ellipsosporum QUCCCM99, and Desmonostoc danxiaense QUCCCM112 on the growth of bell pepper seedlings (Capsicum annuun L.). Outcomes showed that the maximum treatment dose/concentration $\operatorname{Tr}_{3}$ (i.e., extracts added to a modified Hoagland nutrient solution at $0.6 \%$ concentration) led to highest performance in growth parameters compared with controls and other treatments. The positive effect was dose-dependent with the increase of biomass or extract concentrations. Besides, the soilless experimental results showed that at the highest dose, phycoerythrin exhibited a great positive impact on the bell pepper when compared with the control. Hence, phycoerythrin can be regarded as the plant growth stimulator for bell pepper. In conclusion, all of the three local cyanobacteria strains had the potential of promoting the growth and development of bell pepper with Roholtiella sp. QUCCCM97 exhibiting the highest potential under the described experimental conditions. Consequently, they can be suitable for the formulation of a biofertilizer based on their beneficial performances. Future experiments should focus on field trials using separate or mixtures of the Roholtiella sp. QUCCCM97, Nostoc ellipsosporum QUCCCM99, and Desmonostoc danxiaense QUCCCM112 extracts and biomass as they showed higher seedling growth performances. 
Author Contributions: A.S.B.: Conceptualization, methodology, writing-original draft, investigation, and writing—review and editing, I.S.: Conceptualization, writing—review and editing, funding acquisition, resources, T.A.: Conceptualization, writing-review and editing, formal analysis H.H.: Conceptualization, writing-review and editing, M.C.: Methodology and data acquisition, T.D. and G.A.G.: Data acquisition, isolation of the strain: DNA extraction, PCR seq, R.B.-H.: Conceptualization, writing-review and editing, supervision, funding acquisition, resources. All authors have read and agreed to the published version of the manuscript.

Funding: This work was funded by the Graduate Student Grant (QUST-1-CAS-2020-10) provided by Qatar University. Additionally, all cyanobacteria cultures, biomass production and HVP extraction were covered by the grant NPRP8-1087-1-207 provided by Qatar National Research Fund (a member of The Qatar Foundation). Open Access provided by Qatar University IDC funds of R.B.-H. The statements made herein are solely the responsibility of the authors.

Institutional Review Board Statement: Not applicable.

Informed Consent Statement: Not applicable.

Data Availability Statement: Not applicable.

Acknowledgments: The authors would like to thank the Center for Sustainable Development (CSD) for the provision of cyanobacteria biomass used and permission granted to use their facilities for experimental and analysis. In addition, we are equally grateful to the management of Al Sulaiteen Agricultural and Industrial Complex that supplied us with the bell pepper seedlings. The authors are grateful to the two anonymous reviewers for their valuable comments that resulted in a significant improvement of the final manuscript.

Conflicts of Interest: The authors authoritatively declare that there is no current or potential conflict of interest.

\section{References}

1. Savci, S. An agricultural pollutant: Chemical fertilizer. Int. J. Environ. Sci. Dev. 2012, 3, 73-80. [CrossRef]

2. Lee, K.-E.; Adhikari, A.; Kang, S.-M.; You, Y.-H.; Joo, G.-J.; Kim, J.-H.; Kim, S.-J.; Lee, I.-J. Isolation and characterization of the high silicate and phosphate solubilizing novel strain Enterobacter ludwigii GAK2 that promotes growth in rice plants. Agronomy 2019, 9, 144. [CrossRef]

3. Agegnehu, G.; Bass, A.; Nelson, P.; Bird, M. Benefits of biochar, compost and biochar-compost for soil quality, maize yield and greenhouse gas emissions in a tropical agricultural soil. Sci. Total Environ. 2016, 543, 295-306. [CrossRef] [PubMed]

4. Chagnon, M.; Kreutzweiser, D.; Mitchell, E.A.; Morrissey, C.A.; Noome, D.A.; Van der Sluijs, J.P. Risks of large-scale use of systemic insecticides to ecosystem functioning and services. Environ. Sci. Pollut. Res. 2015, 22, 119-134. [CrossRef]

5. Hallmann, C.A.; Foppen, R.P.B.; Van Turnhout, C.A.M.; De Kroon, H.; Jongejans, E. Declines in insectivorous birds are associated with high neonicotinoid concentrations. Nature 2014, 511, 341-343. [CrossRef]

6. Srivastava, P.; Singh, R.; Bhadouria, R.; Tripathi, S.; Singh, P.; Singh, H.; Raghubanshi, A.S. Organic amendment impact on SOC dynamics in dry tropics: A possible role of relative availability of inorganic-N pools. Agric. Ecosyst. Environ. 2016, 235, 38-50. [CrossRef]

7. Van Der Sluijs, J.P.; Amaral-Rogers, V.; Belzunces, L.P.; Van Lexmond, M.F.I.J.B.; Bonmatin, J.-M.; Chagnon, M.; Downs, C.A.; Furlan, L.; Gibbons, D.W.; Giorio, C.; et al. Conclusions of the Worldwide Integrated Assessment on the risks of neonicotinoids and fipronil to biodiversity and ecosystem functioning. Environ. Sci. Pollut. Res. 2015, 22, 148-154. [CrossRef]

8. Abinandan, S.; Subashchandrabose, S.R.; Venkateswarlu, K.; Megharaj, M. Soil microalgae and cyanobacteria: The biotechnological potential in the maintenance of soil fertility and health. Crit. Rev. Biotechnol. 2019, 39, 981-998. [CrossRef]

9. Chittora, D.; Meena, M.; Barupal, T.; Swapnil, P.; Sharma, K. Cyanobacteria as a source of biofertilizers for sustainable agriculture. Biochem. Biophys. Rep. 2020, 22, 100737. [CrossRef]

10. Kheirfam, H.; Sadeghi, S.H.; Darki, B.Z. Soil conservation in an abandoned agricultural rain-fed land through inoculation of cyanobacteria. Catena 2020, 187, 104341. [CrossRef]

11. Saadaoui, I.; Sedky, R.; Rasheed, R.; Bounnit, T.; AlMahmoud, A.; Elshekh, A.; Dalgamouni, T.; Al Jmal, K.; Das, P.; Al Jabri, H. Assessment of the algae-based biofertilizer influence on date palm (Phoenix dactylifera L.) cultivation. J. Appl. Phycol. 2018, 31, 457-463. [CrossRef]

12. Jaiswal, P.; Prasanna, R.; Kashyap, A.K. Modulation of carbonic anhydrase activity in two nitrogen fixing cyanobacteria, Nostoc calcicola and Anabaena sp. J. Plant Physiol. 2005, 162, 1087-1094. [CrossRef]

13. Shariatmadari, Z.; Riahi, H.; Hashtroudi, M.S.; Ghassempour, A.; Aghashariatmadary, Z. Plant growth promoting cyanobacteria and their distribution in terrestrial habitats of Iran. Soil Sci. Plant Nutr. 2013, 59, 535-547. [CrossRef]

14. Dunker, S. Book Review on: The Cell Biology of Cyanobacteria; Flores, E., Herrero, A., Eds.; Caister Academic Press: Norfolk, UK, 2014; p. 308. ISBN 978-1-908230-38-6. 
15. Dorina, S.; Judith, S.; Björn, W.; Schwing, J.; Andrea, S.; Kai, M.; Roland, U. A new strategy for a combined isolation of EPS and pigments from cyanobacteria. J. Appl. Phycol. 2020, 32, 1729-1740. [CrossRef]

16. Vaishampayan, A.; Sinha, R.P.; Hader, D.-P.; Dey, T.; Gupta, A.K.; Bhan, U.; Rao, A.L. Cyanobacterial biofertilizers in rice agriculture. Bot. Rev. 2001, 67, 453-516. [CrossRef]

17. Mishra, U.; Pabbi, S. Cyanobacteria: A potential biofertilizer for rice. Resonance 2004, 9, 6-10. [CrossRef]

18. Shariatmadari, Z.; Riahi, H.; Abdi, M.; Hashtroudi, M.S.; Ghassempour, A. Impact of cyanobacterial extracts on the growth and oil content of the medicinal plant Mentha piperita L. J. Appl. Phycol. 2015, 27, 2279-2287. [CrossRef]

19. Garlapati, D.; Chandrasekaran, M.; Devanesan, A.; Mathimani, T.; Pugazhendhi, A. Role of cyanobacteria in agricultural and industrial sectors: An outlook on economically important byproducts. Appl. Microbiol. Biotechnol. 2019, 103, 4709-4721. [CrossRef]

20. Jaeschke, D.P.; Mercali, G.D.; Marczak, L.D.F.; Mueller, G.; Frey, W.; Gusbeth, C. Extraction of valuable compounds from Arthrospira platensis using pulsed electric field treatment. Bioresour. Technol. 2019, 283, 207-212. [CrossRef]

21. Singh, J.S.; Kumar, A.; Rai, A.N.; Singh, D.P. Cyanobacteria: A precious bio-resource in agriculture, ecosystem, and environmental sustainability. Front. Microbiol. 2016, 7, 529. [CrossRef]

22. Misra, S.; Kaushik, B. Growth promoting substances of cyanobacteria. I: Vitamins and their influence on rice plant. Proc. Indian Natl. Sci. Acad. Part B Biol. Sci. 1989, 55, 295-300.

23. Misra, S.; Kaushik, B. Growth promoting substances of cyanobacteria II. Detection of amino acids, sugars and auxins. Proc. Indian Sci. Acad. B. 1989, 55, 499-504.

24. Karthikeyan, N.; Prasanna, R.; Nain, L.; Kaushik, B.D. Evaluating the potential of plant growth promoting cyanobacteria as inoculants for wheat. Eur. J. Soil Biol. 2007, 43, 23-30. [CrossRef]

25. Obana, S.; Miyamoto, K.; Morita, S.; Ohmori, M.; Inubushi, K. Effect of Nostoc sp. on soil characteristics, plant growth and nutrient uptake. J. Appl. Phycol. 2007, 19, 641-646. [CrossRef]

26. Kumar, M.; Singh, D.P.; Prabha, R.; Sharma, A.K. Role of cyanobacteria in nutrient cycle and use efficiency in the soil. In Nutrient Use Efficiency: From Basics to Advances; Springer: Berlin/Heidelberg, Germany, 2015; pp. 163-171.

27. Al Shrouf, A. Hydroponics, aeroponic and aquaponic as compared with conventional farming. Am. Sci. Res. J. Eng. Technol. Sci. (ASRJETS) 2017, 27, 247-255.

28. Al-Karaki, G.N.; Al-Hashimi, M. Green fodder production and water use efficiency of some forage crops under hydroponic conditions. ISRN Agron. 2012, 2012, 924672. [CrossRef]

29. Maqubela, M.P.; Mnkeni, P.N.S.; Muchaonyerwa, P.; D'Acqui, L.P.; Pardo, M.T. Effects of cyanobacteria strains selected for their bioconditioning and biofertilization potential on maize dry matter and soil nitrogen status in a South African soil. Soil Sci. Plant Nutr. 2010, 56, 552-559. [CrossRef]

30. Godlewska, K.; Michalak, I.; Pacyga, P.; Baśladyńska, S.; Chojnacka, K. Potential applications of cyanobacteria: Spirulina platensis filtrates and homogenates in agriculture. World J. Microbiol. Biotechnol. 2019, 35, 80. [CrossRef]

31. Bosland, P.W.; Votava, E.J.; Votava, E.M. Peppers: Vegetable and Spice Capsicums; CABI: Wallingford, UK, 2012 ; Volume 22.

32. Hoagland, D.R.; Arnon, D.I. The water-culture method for growing plants without soil. In Circular. California Agricultural Experiment Station; CABI: Wallingford, UK, 1950; Volume 347, p. 32.

33. Saadaoui, I.; Al Ghazal, G.; Bounnit, T.; Al Khulaifi, F.; Al Jabri, H.; Potts, M. Evidence of thermo and halotolerant Nannochloris isolate suitable for biodiesel production in Qatar Culture Collection of Cyanobacteria and Microalgae. Algal Res. 2016, 14, 39-47. [CrossRef]

34. Stanier, R.Y.; Kunisawa, R.; Mandel, M.; Cohen-Bazire, G. Purification and properties of unicellular blue-green algae (order Chroococcales). Bacteriol. Rev. 1971, 35, 171. [CrossRef]

35. Saadaoui, I.; Cherif, M.; Rasheed, R.; Bounnit, T.; Ben Hmadou, R.; Manning, S.; Al Jabri, H. Screening of Fresh water and Sea water Microalgae strains from Qatar for feed supplement production. In Qatar Foundation Annual Research Conference Proceedings; Hamad bin Khalifa University Press (HBKU Press): Ar-Rayyan, Qatar, 2018; Volume 2018.

36. Pitcher, D.; Saunders, N.; Owen, R. Rapid extraction of bacterial genomic DNA with guanidium thiocyanate. Lett. Appl. Microbiol. 1989, 8, 151-156. [CrossRef]

37. Kiselev, K.; Dubrovina, A.; Tyunin, A. The methylation status of plant genomic DNA influences PCR efficiency. J. Plant Physiol. 2015, 175, 59-67. [CrossRef] [PubMed]

38. Edgar, R.C. MUSCLE: Multiple sequence alignment with high accuracy and high throughput. Nucleic Acids Res. 2004, 32, 1792-1797. [CrossRef] [PubMed]

39. Kumar, S.; Stecher, G.; Li, M.; Knyaz, C.; Tamura, K. MEGA X: Molecular evolutionary genetics analysis across computing platforms. Mol. Biol. Evol. 2018, 35, 1547. [CrossRef] [PubMed]

40. Stecher, G.; Tamura, K.; Kumar, S. Molecular evolutionary genetics analysis (MEGA) for macOS. Mol. Biol. Evol. 2020, 37, 1237-1239. [CrossRef]

41. Taiz, L.; Zeiger, E. Photosynthesis: The light reactions. Plant Physiol. 2010, 5, 163-198.

42. Hsieh-Lo, M.; Castillo, G.; Ochoa-Becerra, M.A.; Mojica, L. Phycocyanin and phycoerythrin: Strategies to improve production yield and chemical stability. Algal Res. 2019, 42, 101600. [CrossRef]

43. Garcia-Gonzalez, J.; Sommerfeld, M.R. Biofertilizer and biostimulant properties of the microalga Acutodesmus dimorphus. J. Appl. Phycol. 2016, 28, 1051-1061. [CrossRef] 
44. Sharma, N.K.; Tiwari, S.P.; Tripathi, K.; Rai, A.K. Sustainability and cyanobacteria (blue-green algae): Facts and challenges. J. Appl. Phycol. 2011, 23, 1059-1081. [CrossRef]

45. Irisarri, P.; Gonnet, S.; Monza, J. Cyanobacteria in Uruguayan rice fields: Diversity, nitrogen fixing ability and tolerance to herbicides and combined nitrogen. J. Biotechnol. 2001, 91, 95-103. [CrossRef]

46. Jha, M.N.; Prasad, A.N. Efficacy of new inexpensive cyanobacterial biofertilizer including its shelf-life. World J. Microbiol. Biotechnol. 2006, 22, 73-79. [CrossRef]

47. Pereira, I.; Ortega, R.; Barrientos, L.; Moya, M.; Reyes, G.; Kramm, V. Development of a biofertilizer based on filamentous nitrogen-fixing cyanobacteria for rice crops in Chile. J. Appl. Phycol. 2009, 21, 135-144. [CrossRef]

48. Tarakhovskaya, E.R.; Maslov, Y.I.; Shishova, M.F. Phytohormones in algae. Russ. J. Plant Physiol. 2007, 54, 163-170. [CrossRef]

49. Dias, J.S. Nutritional quality and health benefits of vegetables: A review. Food Nutr. Sci. 2012, 3, 1354-1374. [CrossRef]

50. Riahi, H.; Shariatmadari, Z.; Khanjir, M.; Azizi, A. Effect of Anabaena vaginicola inoculum on growth of pot plants. In International Symposium on Growing Media, Composting and Substrate Analysis 1013; ISHS: Leuven, Belgium, 2011.

51. Gantar, M.; Kerby, N.W.; Rowell, P.; Obreht, Z.; Scrimgeour, C. Colonization of wheat (Triticum vulgare L.) by N2 ${ }^{-}$fixing cyanobacteria: IV. Dark nitrogenase activity and effects of cyanobacteria on natural $15 \mathrm{~N}$ abundance in the plants. New Phytol. 1995, 129, 337-343. [CrossRef]

52. Nilsson, M.; Bhattacharya, J.; Rai, A.N.; Bergman, B. Colonization of roots of rice (Oryza sativa) by symbiotic Nostoc strains. New Phytol. 2002, 156, 517-525. [CrossRef]

53. Michalak, I.; Chojnacka, K.; Dmytryk, A.; Wilk, R.; Gramza, M.; Rój, E. Evaluation of supercritical extracts of algae as biostimulants of plant growth in field trials. Front. Plant Sci. 2016, 7, 1591. [CrossRef]

54. Sobiechowska-Sasim, M.; Ston-Egiert, J.; Kosakowska, A. Quantitative analysis of extracted phycobilin pigments in cyanobacteriaan assessment of spectrophotometric and spectrofluorometric methods. J. Appl. Phycol. 2014, 26, 2065-2074. [CrossRef]

55. Hegazi, A.Z.; Mostafa, S.S.; Ahmed, H.M. Influence of different cyanobacterial application methods on growth and seed production of common bean under various levels of mineral nitrogen fertilization. Nat. Sci. 2010, 8, $183-194$.

56. Wuang, S.C.; Khin, M.C.; Chua, P.Q.D.; Luo, Y.D. Use of Spirulina biomass produced from treatment of aquaculture wastewater as agricultural fertilizers. Algal Res. 2016, 15, 59-64. [CrossRef]

57. Aghofack-Nguemezi, J.; Schinzoumka, P.; Tatchago, V. Effects of extracts or powder of Jatropha curcas and Spirulina platensis on the growth and development of tomato plant. J. Appl. Biosci. 2015, 90, 8413-8420. [CrossRef]

58. Kumari, R.; Kaur, I.; Bhatnagar, A.K. Effect of aqueous extract of Sargassum johnstonii Setchell \& Gardner on growth, yield and quality of Lycopersicon esculentum Mill. J. Appl. Phycol. 2011, 23, 623-633.

59. Herrera, R.M.H.; Santacruz-Ruvalcaba, F.; Ruiz-López, M.A.; Norrie, J.; Hernández-Carmona, G. Effect of liquid seaweed extracts on growth of tomato seedlings (Solanum lycopersicum L.). J. Appl. Phycol. 2014, 26, 619-628. [CrossRef]

60. Mógor, Á.; Ördög, V.; Lima, G.P.P.; Molnár, Z.; Mógor, G. Biostimulant properties of cyanobacterial hydrolysate related to polyamines. J. Appl. Phycol. 2018, 30, 453-460. [CrossRef]

61. Tuhy, Ł.; Samoraj, M.; Witkowska, Z.; Chojnacka, K. Biofortification of maize with micronutrients by Spirulina. Open Chem. 2015, 13, 1119-1126. [CrossRef]

62. Nanda, B.; Tripathy, S.K.; Padhi, S. Effect of algalization on seed germination of vegetable crops. World J. Microbiol. Biotechnol. 1991, 7, 622-623. [CrossRef]

63. Shanab, S.M.; Saker, M.M.; Abdel-Rahman, M.H. Crude extracts of some fresh water cyanobacteria have auxin-like activity on potato tissue culture. Arab. J. Biotechnol. 2003, 6, 297-312.

64. Gupta, A.; Gupta, K. The effect of Phormidium foveolarum extract on growth and development of pea seedlings. Labdev J. Sci. Technol. B 1970, 8, 151-154.

65. Shukla, A.C.; Gupta, A.B. Influence of algal growth-promoting substances on growth, yield and protein contents of rice plants. Nature 1967, 213, 744. [CrossRef]

66. Mutale-Joan, C.; Redouane, B.; Najib, E.; Yassine, K.; Lyamlouli, K.; Laila, S.; Zeroual, Y.; Hicham, E.A. Screening of microalgae liquid extracts for their bio stimulant properties on plant growth, nutrient uptake and metabolite profile of Solanum lycopersicum L. Sci. Rep. 2020, 10, 2820. [CrossRef] 